\title{
Investigate THe Output Behavior of Alkaline Fuel Cell's (AFC's) Parameters : Flow Rate \& Supply Pressure
}

\author{
Md. Siddikur Rahman ${ }^{1, \mathrm{a}}$, Ridown Rashid Riadh ${ }^{2, \mathrm{~b}}$ and Shuva Paul ${ }^{2, \mathrm{~b}}$ \\ ${ }^{1,2}$ Department of Electrical and Electronic Engineering, American International \\ University-Bangladesh, Dhaka, Bangladesh \\ ${ }^{2}$ Department of Electrical and Electronic Engineering, Uttara University, Dhaka, \\ Bangladesh
}

\begin{abstract}
The emergence of fuel cells for the engender of electricity for transferable, compact as well as cosmic, static and automotive purposes prophesies radical changes in electricity supply over coming decagon. This paper presents a study of output behavior of an Alkaline Fuel Cell (AFC) parameters, like flow rates as well as supply pressure. A substantial dispense of research has taken place on fuel cells, which manipulate hydrogen as well as oxygen as their fuel. One of the main objectives for this interest is that fuel cells propound the best criteria for encountering the stipulations of zero emission vehicles, and thus are expected to be the prime users of hydrogen in the alongside future. A $2.4 \mathrm{~kW}-48 \mathrm{Vdc}$ AFC Simulink model is employed in this analysis and observe how the output behaves.
\end{abstract}

\section{KEYWORDS}

AFC; Fuel flow rate; Air flow rate; Fuel supply pressure; Air supply pressure; Simulink; MATLAB.

\section{INTRODUCTION}

Fuel cells are salient authorizing technology for the state's energy portfolio and have the embryonic to restructure the way to power this world, propound cleaner, more-efficient alternatives to the combustion of gasoline and other fossil fuels. Fuel cells have the embryonic to substitute the internal-combustion engine in conveyances and provide power in stationary as well as portable power appeals because they are fuel-flexible, clean and energy-efficient [1].

Fuel cells are classified primarily by the kind of electrolyte they employ. This ranking regulates the kind of electro-chemical responses which take place in the cell, the genre of catalysts have necessitated, the temperature span in which the cell performs, the fuel necessitated and other components. These characteristics, in turn, affect the applications for which these cells are most suitable [2].

DOI : 10.14810/elelij.2015.4409 
Every types of fuel cell have some unique as well as important features to specific application; however Alkaline Fuel Cell has some unique features over all type of fuel cell. Alkali fuel cell (AFC) has been operated on compressed hydrogen and oxygen. They generally use a solution of potassium hydroxide (in chemical, $\mathrm{KOH}$ ) in water as their electrolyte [3].

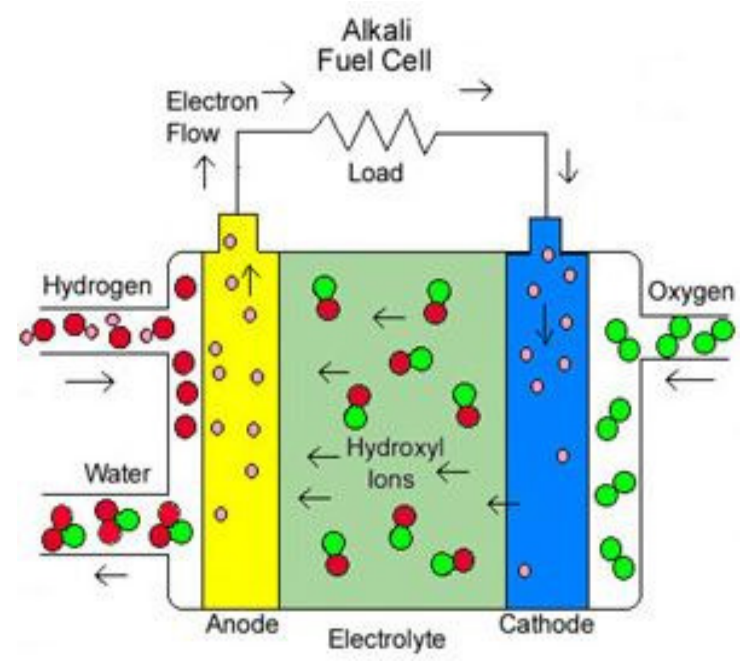

Fig.1. Alkali Fuel Cell [3]

By elucidation Aqueous potassium hydroxide soaked in a porous matrix, or alkaline polymer membrane, type of electrolyte has been used in AFC. The range of stack size of AFC is $1 \mathrm{~kW}$ to $100 \mathrm{~kW}$. Electrical efficiency (LHV) of AFC is about $60 \%$. AFC has been used in some application such as military, space, backup power and transportation. AFC has some salient advantages such as (i) Wider range of stable materials allows lower cost components; (ii) Low temperature; (iii) Quick start-up [4]. , it has been known to all that flow rate means quantity of a gas or liquid moving through a pipe or channel within a given or standard period (usually a minute or hour). So fuel flow rate means quantity of fuel moving through pipe or channel within a given time or standard period. The definition of Air flow rate is almost same as fuel flow rate, in air flow rate using air instead of fuel $[5,6]$.

By elucidation, it has been known to all that supply pressure means the pressure supplied to the high pressure or inlet side of a regulator. So fuel supply pressure means quantity of pressure which has been supplied to inlet side of a regulator. The definition of Air Supply pressure is almost same, in air supply pressure using air instead of air [7, 8].

The objective of this paper is to investigate the output behavior in a generic model parameterized to represent one type of fuel cell stacks fed with hydrogen and air. A Simulink model has been taken as test system to investigate the output behaviour over time. This paper is organised as follows: Section 2 presents a brief overview of fuel cell, it's working principle as well as types of fuel cell. A brief overview of alkaline fuel cell and it's working principle has been presented in section 3. Simulation results along with analysis have been discussed in section 4. At the end section 5 concludes the work highlighting the major contributions. 


\section{Fuel Cell \& Working Principle}

A fuel cell has been used the chemical energy of hydrogen to cleanly and efficiently produce electricity with water and heat as by-products. Fuel cells are idiosyncratic in terms of the diversity of their embryonic appeals; they have dispensed energy for structures as sizeable as an efficacy power station and as microscopic as a laptop computer.

\subsection{Fuel Cell}

In 1840, Fuel cells had been invented but have been resuscitated as an exemplary pretender for an alternative power source research. Fuel cell is an electrochemical device as well as have been generated an electric current as a result of chemical response linking between a fuel (frequently used as hydrogen) as well as oxidant with the only ramification of the operation of being heat as well as water. Since no combustion has been taken place, efficiencies of more than two times that of a traditional IC engine are possible. A fuel cell system has been consisted of a stack of identical cells which has been combined to achieve the desired power output as well as has been shown in below. Each independent cell congregation has been consisted of an electrolyte membrane which has been sandwiched between two catalyst impregnated anode as well as cathode electrodes. This fundamental cell has further been sandwiched between two bipolar plates which have been used to deliver the reactants to the working fuel cell.

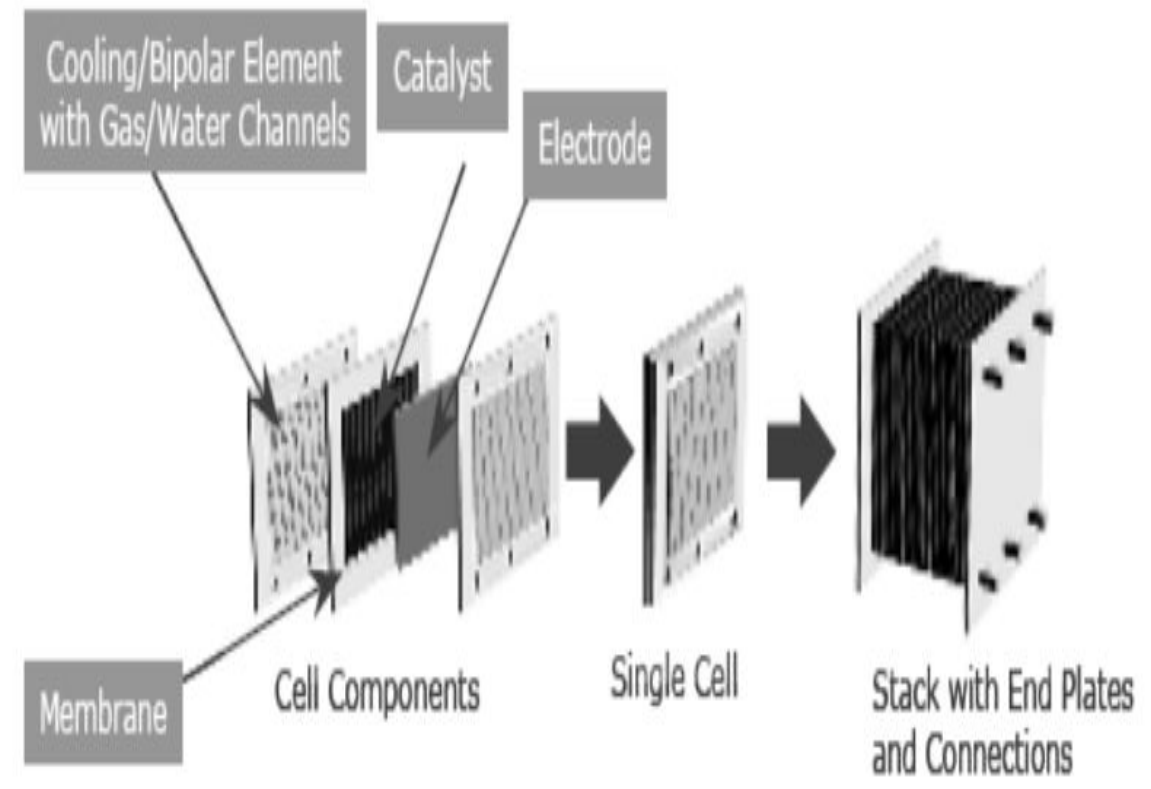

Fig.2. Constituents of a Fuel cell stack [9] 


\subsection{Working Principle of Fuel Cell}

It has been noted that the electrochemical response which has been taken place at each electrode vary according to the fuel cell type as well as consequently the electrolyte has been used. This

conference will however be restricted to the most same type of fuel cell, which is the acid electrolyte hydrogen fuel cell. The working postulates of a fuel cell have been best to understand by examining a cross-section through an anode/membrane/cathode cell congregation as shown in below.

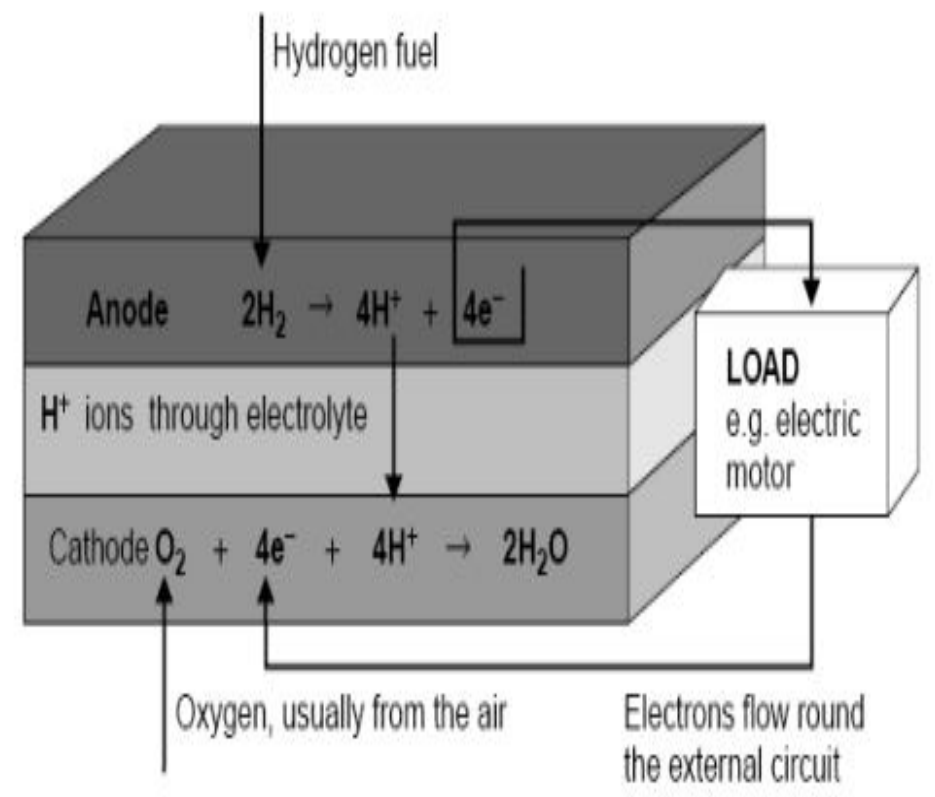

Fig.3. Electrochemical reactions of Fuel cell [10]

\subsection{Types of Fuel Cell}

Different fuel cells have been explored over time which are characterised according to the electrolyte that they use and the steering reactions. Most common fuel cells types and their application in industry are summarised below $[10,11]$. 
TABLE 1. SUMMARY OF DifFERENT TyPES OF FUEL CELL

\begin{tabular}{|c|c|c|c|}
\hline $\begin{array}{c}\text { Fuel Cell } \\
\text { Type }\end{array}$ & $\begin{array}{c}\text { Mobile } \\
\text { ion }\end{array}$ & $\begin{array}{c}\text { Operating } \\
\text { Temperatur } \\
\text { e }\end{array}$ & Applications \& Notes \\
\hline $\begin{array}{c}\text { Proton } \\
\text { Exchange } \\
\text { Membrane } \\
\text { Fuel Cell } \\
\text { (PEMFC) }\end{array}$ & $\mathrm{H}^{+}$ & $(30-100){ }^{\circ} \mathrm{C}$ & $\begin{array}{l}\text { Conveyances \& mobile } \\
\text { appeals, and for beneath } \\
\text { power CHP systems }\end{array}$ \\
\hline $\begin{array}{l}\text { Direct } \\
\text { Methanol } \\
\text { Fuel Cell } \\
\text { (DMFC) }\end{array}$ & $\mathrm{H}^{+}$ & $(20-90){ }^{\circ} \mathrm{C}$ & $\begin{array}{c}\text { Appropriate for } \\
\text { transportable electronic } \\
\text { systems of underneath } \\
\text { power, running for long- } \\
\text { lasting }\end{array}$ \\
\hline $\begin{array}{l}\text { Phosphori } \\
\text { c Acid } \\
\text { Fuel Cell } \\
\text { (PAFC) }\end{array}$ & $\mathrm{H}^{+}$ & $\sim 220^{\circ} \mathrm{C}$ & $\begin{array}{c}\text { Enormous numbers of } \\
200 \mathrm{~kW} \text { CHP structures in } \\
\text { use }\end{array}$ \\
\hline $\begin{array}{c}\text { Molten } \\
\text { Carbonate } \\
\text { Fuel Cell } \\
\text { (MCFC) }\end{array}$ & $\mathrm{CO}_{3}{ }^{2-}$ & $\sim 650{ }^{\circ} \mathrm{C}$ & $\begin{array}{l}\text { Appropriate for average } \\
\text { to large scale CHP } \\
\text { structures, up to MW } \\
\text { capacity }\end{array}$ \\
\hline $\begin{array}{c}\text { Solid } \\
\text { Oxide Fuel } \\
\text { Cell } \\
\text { (SOFC) }\end{array}$ & $\mathrm{O}^{2-}$ & $\begin{array}{c}(500-1000) \\
{ }^{\circ} \mathrm{C}\end{array}$ & $\begin{array}{c}\text { Appropriate for all } \\
\text { volumes of CHP } \\
\text { structures } 2 \mathrm{~kW} \text { to multi } \\
\text { MW }\end{array}$ \\
\hline $\begin{array}{l}\text { Alkaline } \\
\text { Fuel Cell } \\
\text { (AFC) }\end{array}$ & $\mathrm{OH}^{-}$ & $(50-200){ }^{\circ} \mathrm{C}$ & $\begin{array}{l}\text { Manipulated in space } \\
\text { conveyances such as } \\
\text { Apollo, Shuttle }\end{array}$ \\
\hline
\end{tabular}

However, FCs have assorted conveniences over traditional combustion-root technologies as well as manipulated in passenger conveyances and in many power plants at present. They discharge no ejections at the point of performance, incorporating air pollutants and greenhouse gases which produce vapour as well as cause health issue.

\section{Alkaline Fuel Cell \& Working Principle}

The Bacon fuel cell is also known as the Alkaline Fuel Cell (AFC); had invented by a British inventor. Alkaline Fuel Cell (AFC) had one of the first fuel cell technologies which had been developed as well as they were the first type of fuel cell which is widely used in the U.S. space program to produce water as well as electrical energy on-board spacecraft. AFC's had been used as a solution of potassium hydroxide in water as the electrolyte as well as can be used a variety of non-precious metals as a catalyst at the anode and cathode. AFC's operating temperature is high, 
such as in between $100^{\circ} \mathrm{C}$ and $250^{\circ} \mathrm{C}\left(212^{\circ} \mathrm{F}\right.$ and $\left.482^{\circ} \mathrm{F}\right)$. However, newer AFC designs are operate at lower temperatures of roughly $23^{\circ} \mathrm{C}$ to $70^{\circ} \mathrm{C}\left(74^{\circ} \mathrm{F}\right.$ to $\left.158^{\circ} \mathrm{F}\right)$.

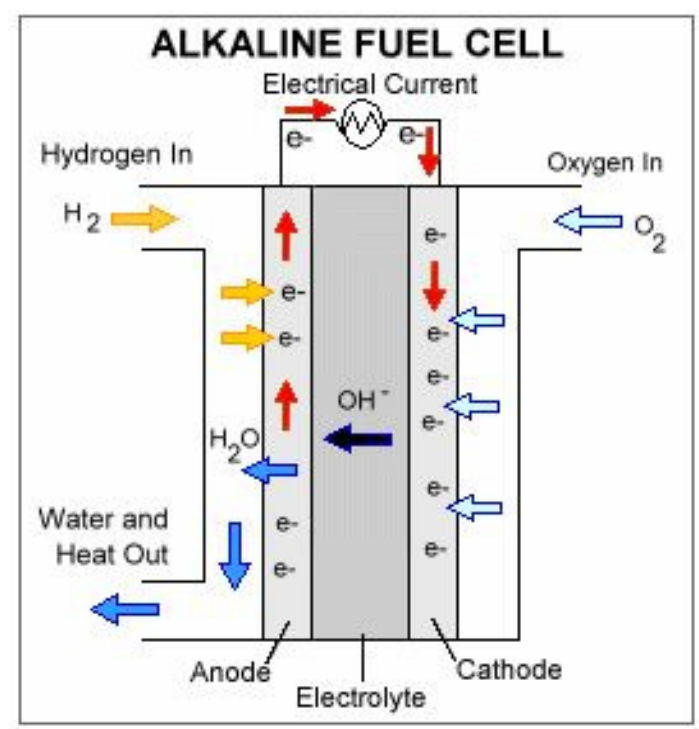

Fig.4. Representation of Alkaline Fuel Cell (AFC) [11]

In recent years, novel AFC's which use a polymer membrane as the electrolyte have been developed. These fuel cells are closely related to conventional PEM fuel cells, except that they use an alkaline membrane instead of an acid membrane. The high performance of AFC's is due to the rate at which electro-chemical reactions take place in the cell. They have also demonstrated efficiencies above $60 \%$ in space applications. Cost is less of a factor for remote locations, such as in space or under the sea. However, to compete effectively in most mainstream commercial markets, these fuel cells will have to become more cost-effective. To be economically viable in large-scale utility applications, AFCs need to reach operating times exceeding 40,000 hours, something that has not yet been achieved due to material durability issues [12].

By utilizing alkaline electrolyte potassium hydroxide $(\mathrm{KOH})$, AFC generate electric power in water based solution. The existence of the hydroxyl ions traversing across the electrolyte allows a circuit to be made as well as electrical energy could be extracted. Fig. 2 illustrates an alkaline fuel cell. At anode section, 2 hydrogen gas molecules are combined with 4 hydroxyl ions with a negative charge to release 4 water molecules and 4 electrons. The redox reaction taking place is oxidation as in (1) $[13,14]$ :

$$
\text { (Oxidation) } 2 \mathrm{H}_{2}+4 \mathrm{OH}^{-} \rightarrow 4 \mathrm{H}_{2} \mathrm{O}+4 \mathrm{e}^{-}
$$

Electrons released in this reaction, reach the cathode through the external circuit and react with water to generate $\left(\mathrm{OH}^{-}\right)$ions. 


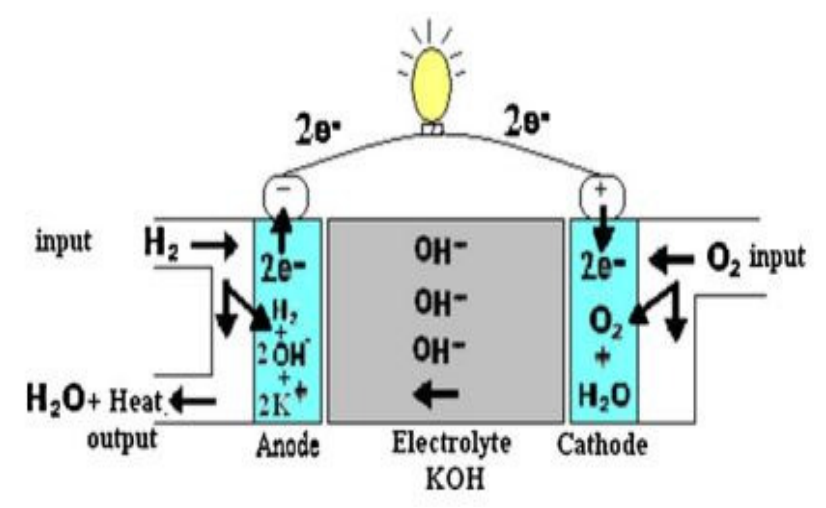

Fig.5. Working Principle representation of Alkaline Fuel Cell (AFC) [15]

At cathode section, oxygen molecule and 2 water molecules combined and absorbed 4 electrons to form 4 negatively charged hydroxyl ions. The occurring redox reaction is reduction as below $[13,14]$ :

(Reduction) $\mathrm{O}_{2}+2 \mathrm{H}_{2} \mathrm{O}+4 \mathrm{e}^{-} \rightarrow 4 \mathrm{OH}^{-}$

AFCs have been considered as the most cost efficient type of fuel cells since the electrolyte used is a standard chemical potassium hydroxide $(\mathrm{KOH})[16]$. There are some major fuel constituents which have impact on AFC and which are summarized in Table II.

TABLE 2. SUMmARY OF MAJOR Fuel CONSTITUENTS IMPACT ON AFC [17]

\begin{tabular}{|c|c|}
\hline Gas Species & Alkaline Fuel Cell (AFC) \\
\hline $\mathrm{H}_{2}$ & Fuel \\
\hline $\mathrm{CO}$ & Poison \\
\hline $\mathrm{CH}_{4}$ & Poison \\
\hline $\mathrm{CO}_{2} \& \mathrm{H}_{2} \mathrm{O}$ & Poison \\
\hline $\mathrm{S}$ as $\left(\mathrm{H}_{2} \mathrm{~S} \& \mathrm{COS}\right)$ & Poison \\
\hline
\end{tabular}

Next section represents the simulation results carried out on a Simulink model based on fuel cell manufacturer's data sheet. 


\section{Test System \& Simulation Result}

In this study, one system (Such as $2.4 \mathrm{~kW}-48 \mathrm{Vdc}$ ) has been considered and the basic block diagram of this system has been shown in Figure 6 [18]. By definition, it has been known to all that Ramp function is a unary real function, simply estimable as the mean of the independent variable as well as its absolute value. It's an input source of this test system. In this study, Boost converter (step-up converter) is a DC to DC power converter with an elevated output voltage than its input voltage. When the operating key is opened, current will be minimized as the impedance is lofty. Previously, the magnetic field is created but will be destroyed to maintain the current flow towards the load. Therefore the polarity will be back-pedaled (means sinister side of inductor will be dissentient now). As a result two sources will be in series causing a lofty voltage to charge the capacitor through the diode D. The DC input to a boost converter can be from many sources as well as batteries, like as amended AC from the mains supply or DC from fuel cells, DC generators and dynamos. This is the reason to use Boost Converter in this study. The converter is loaded by an RL element in three systems and the value of RL element can be varied by this system's, e.g. Since the system is $2.4 \mathrm{~kW}-48 \mathrm{Vdc}$, then the value of RL element is $2.4 \mathrm{~kW}$ with a time constant 1 second.

All results presented in this research were simulated with research analytical tool SimPower Systems based on Matlab. With the help of SimPowerSystems under SimScape division in Matlab results of output behaviour have been measured for changing input values of Ramp Function based on fuel cell stack manufacturer's data sheet [19].

\section{$2.4 \mathrm{~kW}$ - $48 \mathrm{Vdc}$ Alkaline Fuel Cell (AFC)}

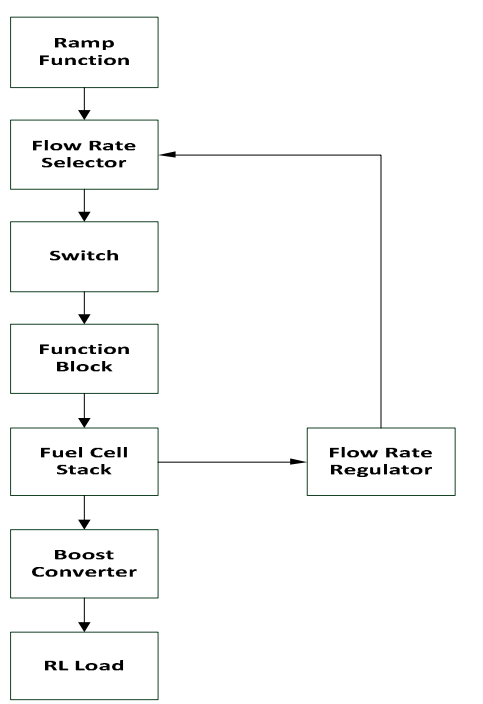

Fig.6. Block representation of $2.4 \mathrm{~kW}-48 \mathrm{Vdc}$ AFC system 
Inside representation of Fuel Cell Stack (above Figure 6) has been presented in Figure 7 below.

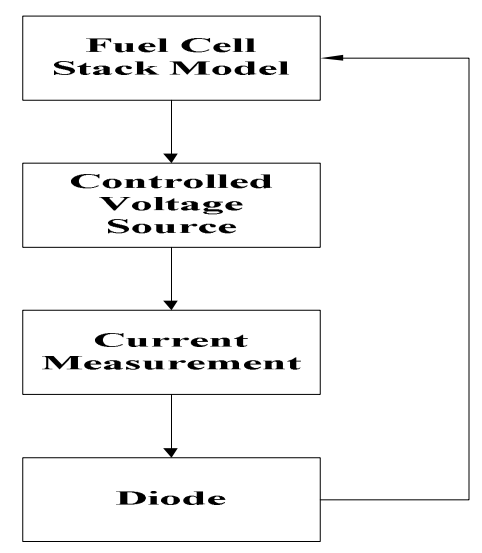

Fig.7. Block representation of Fuel cell stack (inside representation)

The prime essence which has driven the boost converter is the propensity of an inductor to endure changes in flow of electron by generating as well as wrecking a magnetic field. It has been known to all, in a boost converter, the output voltage is always higher than the input voltage. A block representation of boost converter is shown in Figure 8. When the switch has been closed, current flows through the inductor in clockwise direction and the inductor stores some energy by generating a magnetic field. Polarity of the left side of the inductor is positive.

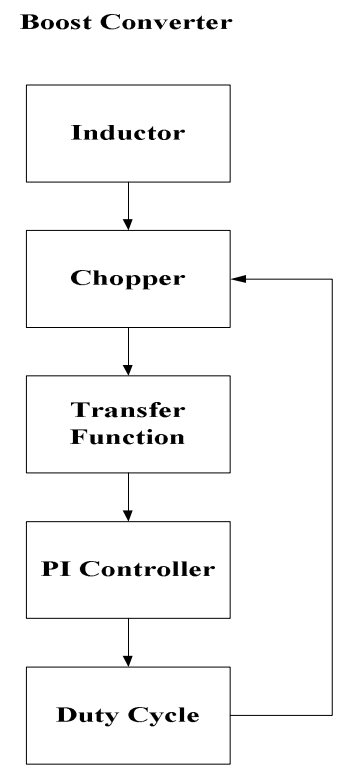

Fig.8. Block representation of Boost Converter 


\section{Case Study 1: Flow Rate}

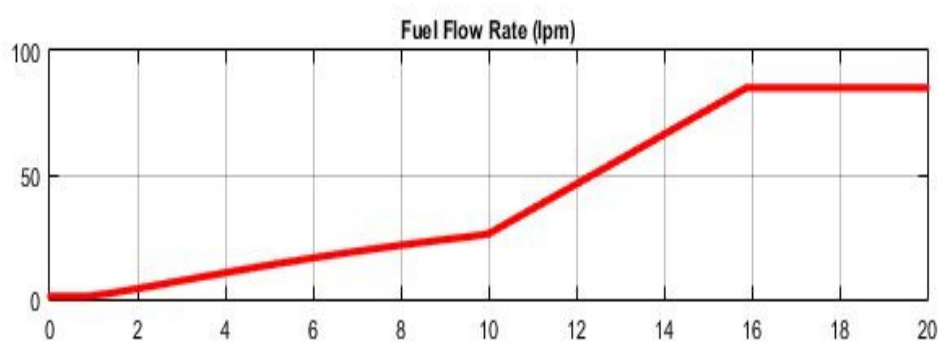

Fig.9. Fuel flow rate (lpm) of $2.4 \mathrm{~kW}-48 \mathrm{Vdc}$ AFC

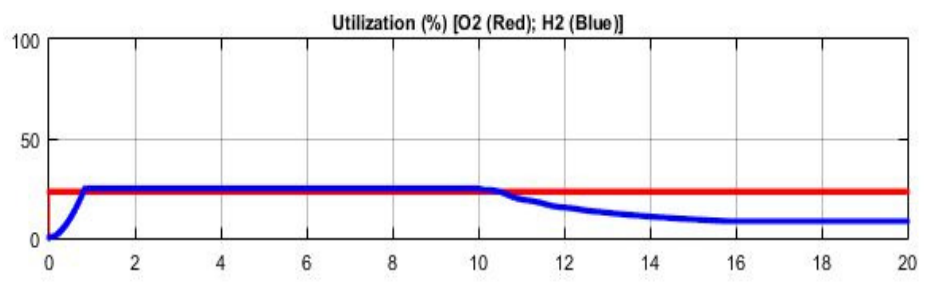

Fig.10. Utilization (\%) $\left[\mathrm{O}_{2}\right.$ (Red), $\mathrm{H}_{2}$ (Blue)] of $2.4 \mathrm{~kW}-48 \mathrm{Vdc}$ AFC

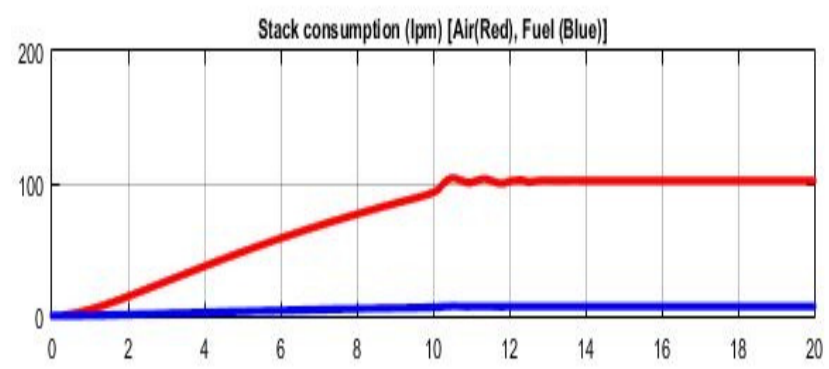

Fig.11. Stack consumption (lpm) [Air (Red), Fuel (Blue)] of 2.4 kW - 48 Vdc AFC

From Figure 10, can be concluded that the utilization of oxygen is about $25 \%$ whereas utilization of hydrogen is not constant (at $0 \mathrm{sec}$. utilization of hydrogen is $0 \%$, at $10 \mathrm{sec}$. utilization of hydrogen is about $25 \%$ and at $20 \mathrm{sec}$. utilization of hydrogen is $10 \%$ ). From Figure 11, can be concluded that the consumption of Air is gradually increasing from $0 \mathrm{sec}$. to $10 \mathrm{sec}$. and after 10 sec. Air consumption is in saturate condition till $20 \mathrm{sec}$. whereas Fuel consumption is almost 0 lpm from $0 \mathrm{sec}$. to $8 \mathrm{sec}$. and at $10 \mathrm{sec}$. fuel consumption is $5 \mathrm{lpm}$ till $20 \mathrm{sec}$. From Figure 12, can be concluded that stack efficiency is $0 \%$ at $0 \mathrm{sec}$. and $20 \mathrm{sec}$.; at $10 \mathrm{sec}$. stack efficiency is about $20 \%$. 
Electrical and Electronics Engineering: An International Journal (ELELIJ) Vol 4, No 4, November 2015

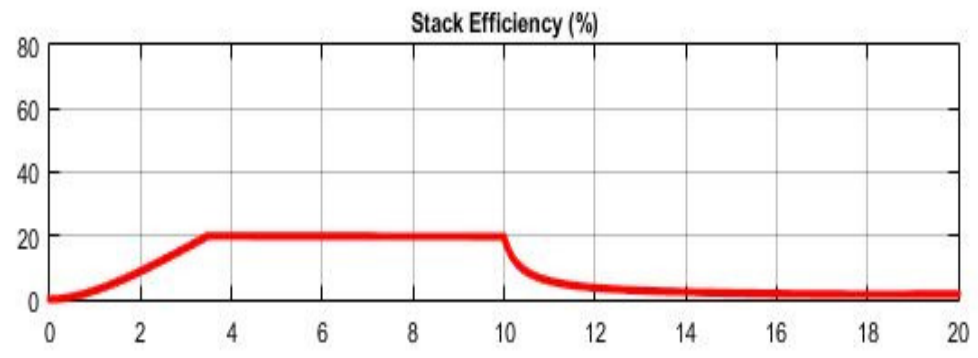

Fig.12. Stack efficiency (\%) of $2.4 \mathrm{~kW}-48 \mathrm{Vdc}$ AFC

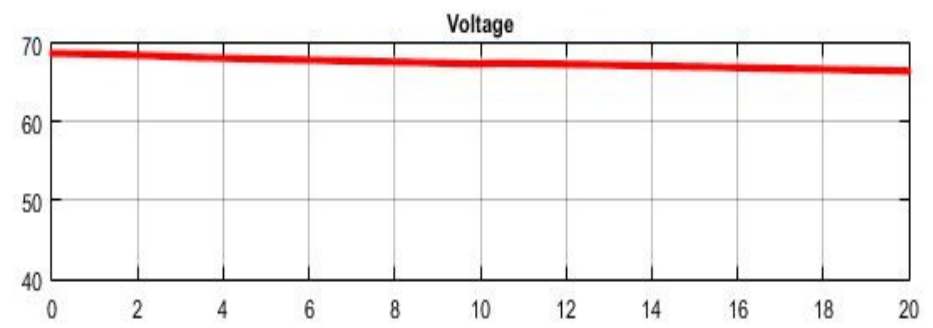

Fig.13. Fuel cell stack voltage of $2.4 \mathrm{~kW}-48 \mathrm{Vdc}$ AFC

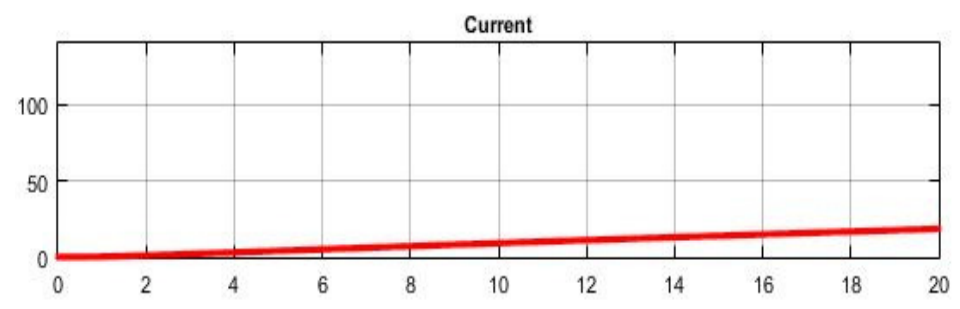

Fig.14. Fuel cell stack current of $2.4 \mathrm{~kW}-48 \mathrm{Vdc}$ AFC

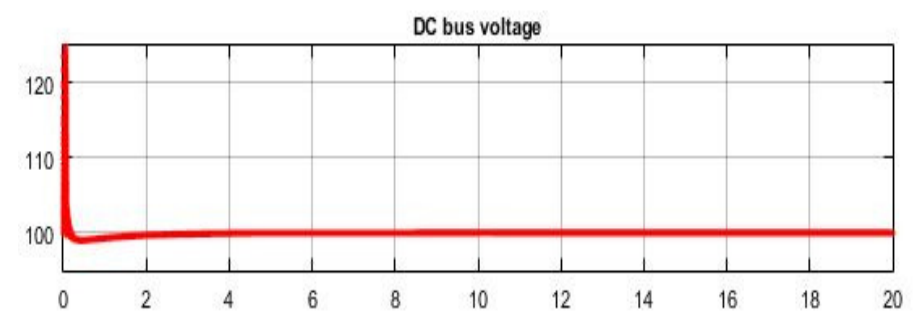

Fig.15. DC bus voltage of $2.4 \mathrm{~kW}-48 \mathrm{Vdc}$ AFC 


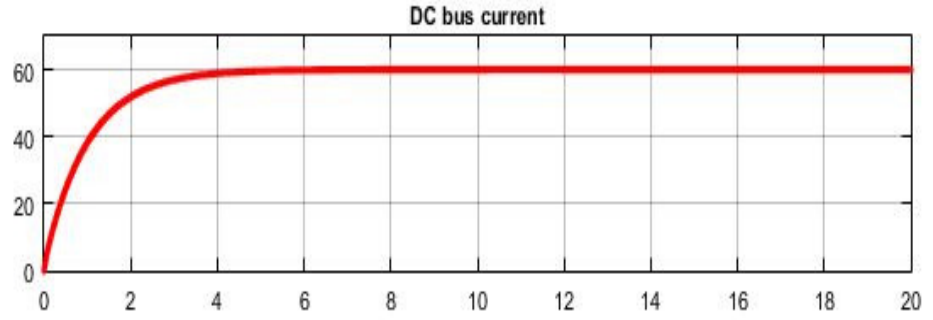

Fig.16. DC bus current of $2.4 \mathrm{~kW}-48 \mathrm{Vdc}$ AFC

Findings of Figure 13, 14, 15 and 16 are summarized and shown in Table III.

Table 3.IMPORTANT MEASUREMENTS of FUEL Flow RATE

\begin{tabular}{|c|c|c|c|c|c|}
\hline \multirow{2}{*}{ System } & \multirow{2}{*}{$\begin{array}{c}\text { Tim } \\
\text { e } \\
\text { (sec.) }\end{array}$} & $\begin{array}{c}\text { Voltage } \\
\text { (Volts) }\end{array}$ & $\begin{array}{c}\text { Current } \\
\text { (Amp) }\end{array}$ & $\begin{array}{c}\text { DC bus } \\
\text { voltage } \\
\text { (Volts) }\end{array}$ & $\begin{array}{c}\text { DC bus } \\
\text { current } \\
\text { (Amp) }\end{array}$ \\
\hline \multirow{2}{*}{$\begin{array}{c}\text { (Am kW }-48 \mathrm{Vdc} \\
\text { AFC }\end{array}$} & 0 & 69 & 0 & 125 & 0 \\
\cline { 2 - 6 } & 10 & 68 & 5 & 100 & 60 \\
\cline { 2 - 6 } & 20 & 67 & 10 & 100 & 60 \\
\hline
\end{tabular}

Findings of Figure $9 \& 17$ are summarized and shown in Table IV

TABLE 4.MEASUREMENTS OF FlOW RATE

\begin{tabular}{|c|c|c|c|}
\hline \multirow{2}{*}{ System } & \multirow{2}{*}{$\begin{array}{c}\text { Time } \\
\text { (sec.) }\end{array}$} & $\begin{array}{c}|c| \\
\text { Fuel Flow Rate } \\
\text { Rate }\end{array}$ & $\begin{array}{c}\text { Air Flow } \\
\text { Rate }\end{array}$ \\
\hline \multirow{2}{*}{$\begin{array}{c}2.4 \mathrm{~kW}-48 \mathrm{Vdc} \\
\text { AFC }\end{array}$} & 0 & 0 & 0 \\
\cline { 2 - 4 } & 10 & 30 & 12 \\
\cline { 2 - 4 } & 20 & 85 & 85 \\
\hline
\end{tabular}

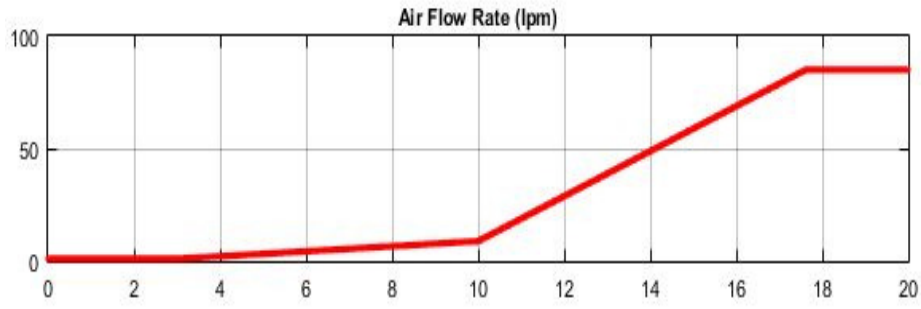

Fig.17. Air flow rate (lpm) of $2.4 \mathrm{~kW}-48 \mathrm{Vdc}$ AFC 
Electrical and Electronics Engineering: An International Journal (ELELIJ) Vol 4, No 4, November 2015

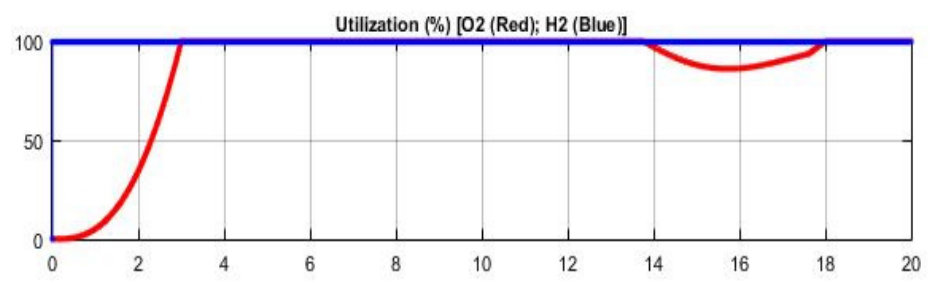

Fig.18. Utilization (\%) $\left[\mathrm{O}_{2}\right.$ (Red), $\mathrm{H}_{2}$ (Blue)] of $2.4 \mathrm{~kW}-48 \mathrm{Vdc}$ AFC

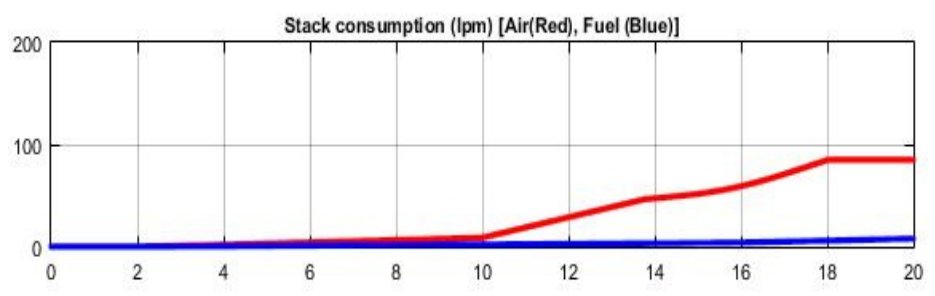

Fig.19. Stack consumption (lpm) [Air (Red), Fuel (Blue)] of $2.4 \mathrm{~kW}-48 \mathrm{Vdc}$ AFC

From Figure 18, can be concluded that the utilization of hydrogen is about $100 \%$ whereas utilization of oxygen is not constant (at $0 \mathrm{sec}$. utilization of oxygen is $0 \%$, at $10 \mathrm{sec}$. utilization of oxygen is about $100 \%$ and at $18 \mathrm{sec}$. utilization of oxygen is $82 \%$ ). From Figure 19, can be concluded that the consumption of Air is gradually increasing from $10 \mathrm{sec}$. to $18 \mathrm{sec}$. and after 18 sec. Air consumption is in saturate condition till $20 \mathrm{sec}$. whereas Fuel consumption is almost 0 lpm from $0 \mathrm{sec}$. to $16 \mathrm{sec}$. and at $18 \mathrm{sec}$. fuel consumption is $5 \%$ till $20 \mathrm{sec}$. From Figure 20, can be concluded that stack efficiency is $80 \%$ at $0 \mathrm{sec}$. to $20 \mathrm{sec}$.

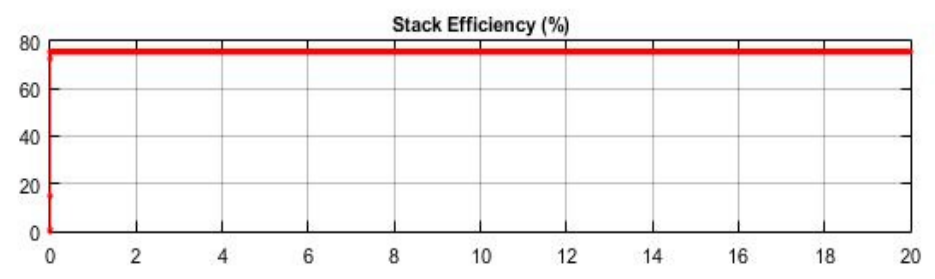

Fig.20. Stack efficiency (\%) of $2.4 \mathrm{~kW}-48 \mathrm{Vdc}$ AFC

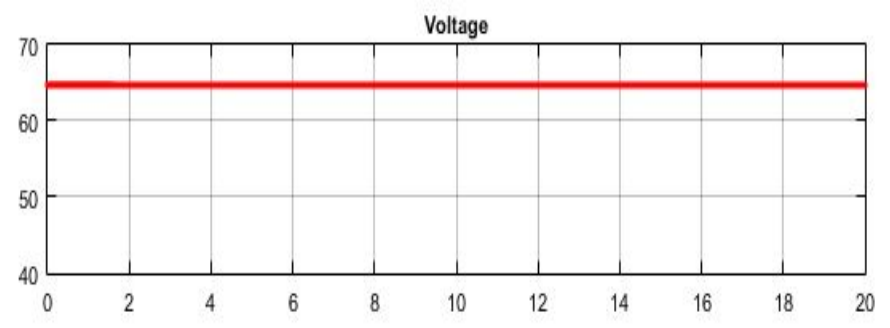

Fig.21. Fuel cell stack voltage of $2.4 \mathrm{~kW}-48 \mathrm{Vdc}$ AFC 
Electrical and Electronics Engineering: An International Journal (ELELIJ) Vol 4, No 4, November 2015

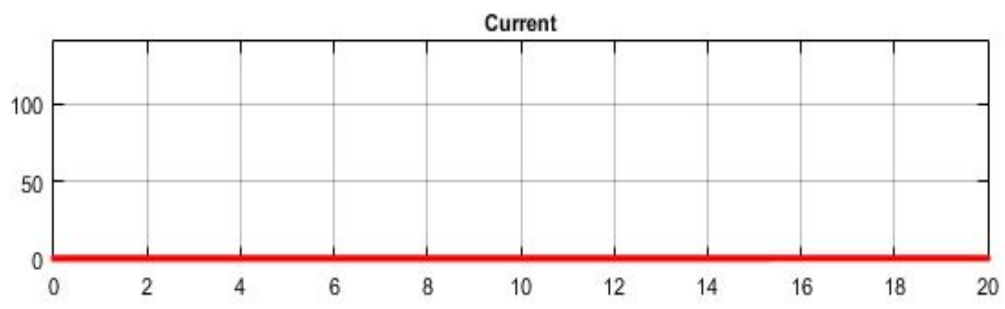

Fig.22. Fuel cell stack current of $2.4 \mathrm{~kW}-48 \mathrm{Vdc}$ AFC

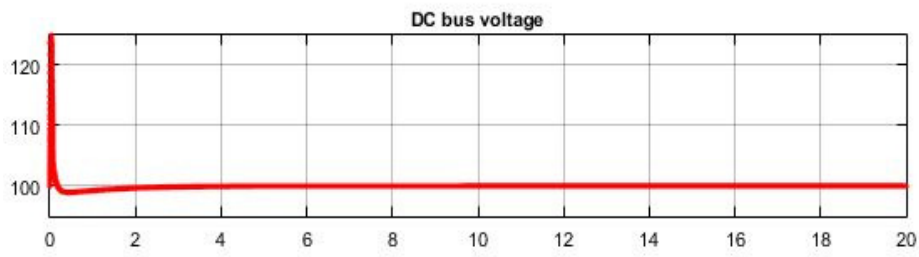

Fig.23. DC bus voltage of $2.4 \mathrm{~kW}-48 \mathrm{Vdc}$ AFC

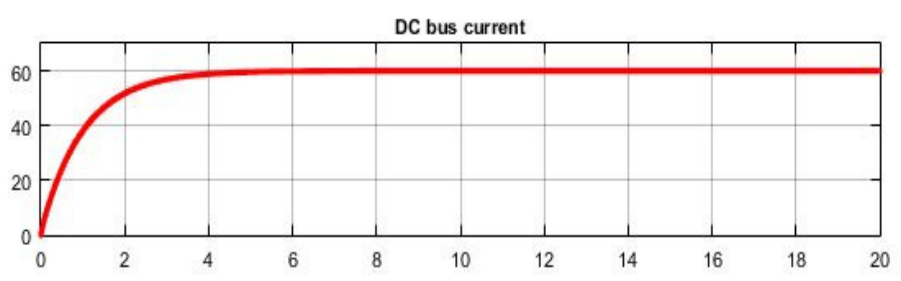

Fig.24. DC bus current of $2.4 \mathrm{~kW}-48$ Vdc AFCFindings of Figure 21, 22, 23 and 24 are summarized and shown in Table $\mathrm{V}$.

Table 5 IMPORTANTS MEASUREMENTS OF AIR FLOW RATE

\begin{tabular}{|c|c|c|c|c|c|}
\hline \multirow{2}{*}{ System } & \multirow{2}{*}{$\begin{array}{c}\text { Time } \\
\text { (sec.) }\end{array}$} & \multicolumn{4}{|c|}{ Air Flow Rate (lpm) } \\
\cline { 3 - 6 } & $\begin{array}{c}\text { Voltage } \\
\text { (Volts) }\end{array}$ & $\begin{array}{c}\text { Current } \\
\text { (Amp) }\end{array}$ & $\begin{array}{c}\text { DC bus } \\
\text { voltage } \\
\text { (Volts) }\end{array}$ & $\begin{array}{c}\text { DC bus } \\
\text { current } \\
\text { (Amp) }\end{array}$ \\
\hline \multirow{2}{*}{$\begin{array}{c}2.4 \mathrm{~kW}-48 \mathrm{Vdc} \\
\text { AFC }\end{array}$} & 0 & 65 & 0 & 125 & 0 \\
\cline { 2 - 6 } & 10 & 65 & 0 & 100 & 60 \\
\cline { 2 - 6 } & 20 & 65 & 0 & 100 & 60 \\
\hline
\end{tabular}




\section{Case Study 2: Supply Pressure}

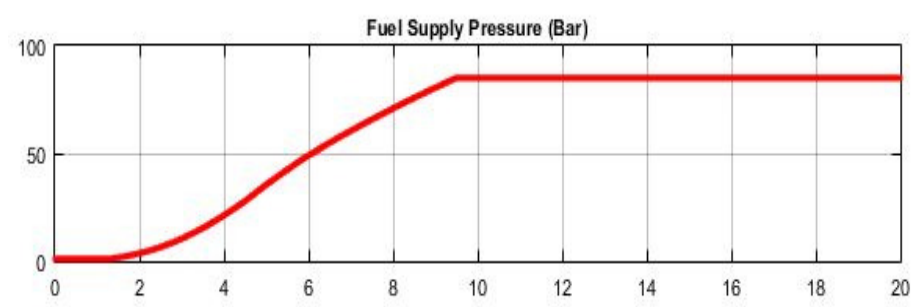

Fig.25. Fuel supply pressure (Bar) of $2.4 \mathrm{~kW}-48 \mathrm{Vdc}$ AFC

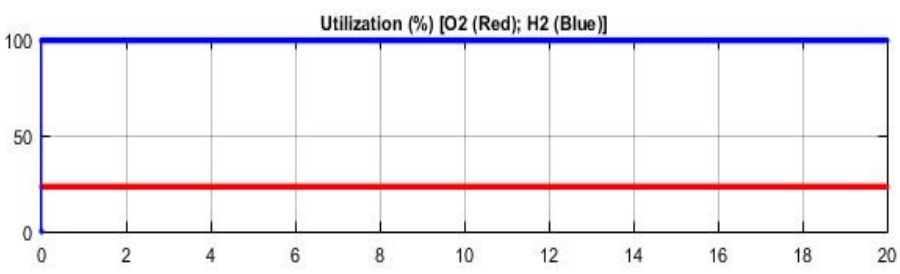

Fig.26. Utilization (\%) $\left[\mathrm{O}_{2}\right.$ (Red), $\mathrm{H}_{2}$ (Blue)] of $2.4 \mathrm{~kW}-48 \mathrm{Vdc}$ AFC

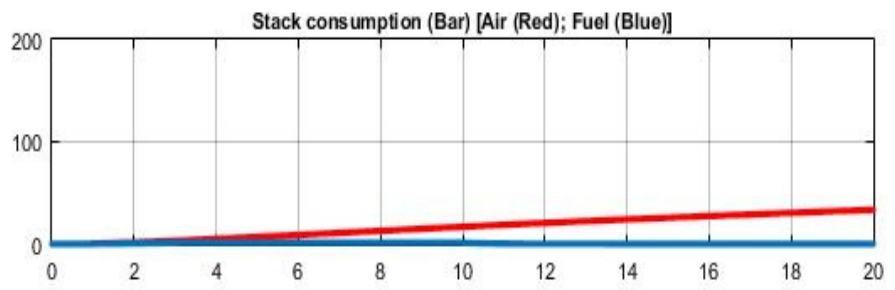

Fig.27. Stack consumption (Bar) [Air (Red), Fuel (Blue)] of 2.4 kW - 48 Vdc AFC

From Figure 26, can be concluded that the utilization of oxygen is about $25 \%$ whereas utilization of hydrogen is about $100 \%$. From Figure 27, can be concluded that the consumption of Air is gradually increasing from $2 \mathrm{sec}$. to $20 \mathrm{sec}$. whereas Fuel consumption is almost 0 Bar from $0 \mathrm{sec}$. to $20 \mathrm{sec}$. From Figure 28, can be concluded that stack efficiency is not constant (at 0 sec. stack efficiency is about $77 \%$, at 10 sec. stack efficiency is about $66 \%$ and at $20 \mathrm{sec}$. stack efficiency is about $69 \%$ ).

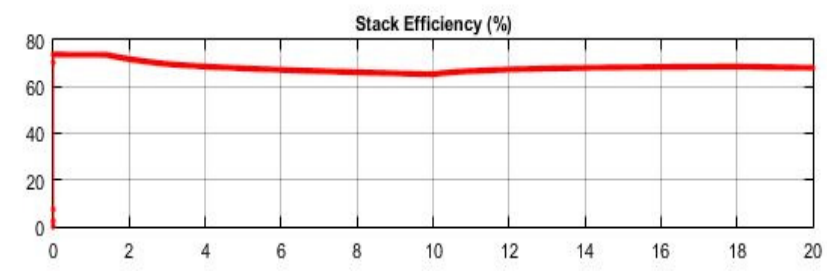

Fig.28. Stack efficiency (\%) of $2.4 \mathrm{~kW}-48 \mathrm{Vdc}$ AFC 
Electrical and Electronics Engineering: An International Journal (ELELIJ) Vol 4, No 4, November 2015

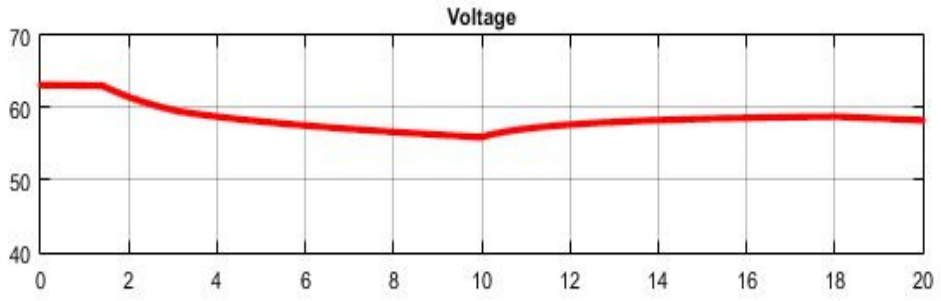

Fig.29. Fuel cell stack voltage of $2.4 \mathrm{~kW}-48 \mathrm{Vdc}$ AFC

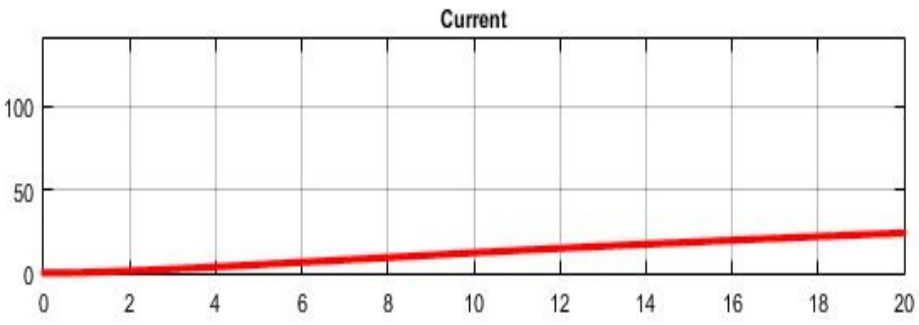

Fig.30. Fuel cell stack current of $2.4 \mathrm{~kW}-48 \mathrm{Vdc}$ AFC

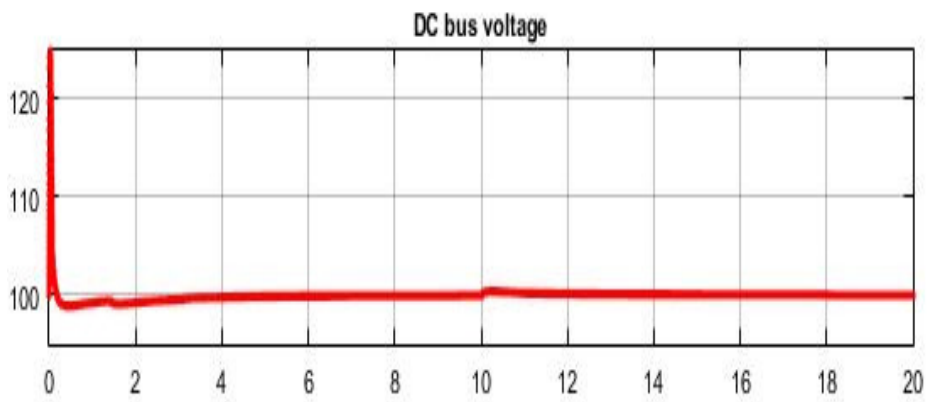

Fig.31. DC bus voltage of $2.4 \mathrm{~kW}-48 \mathrm{Vdc}$ AFC

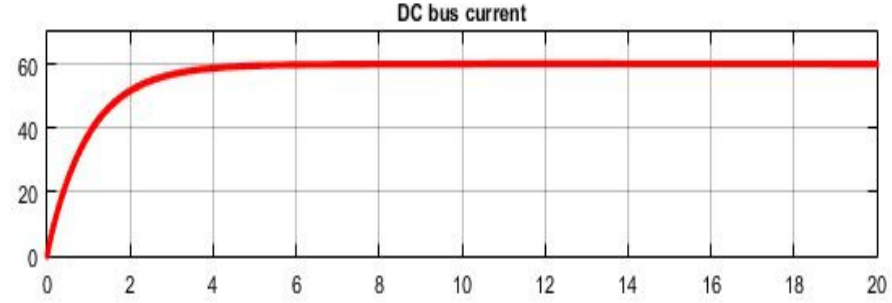

Fig.32. DC bus current of $2.4 \mathrm{~kW}-48 \mathrm{Vdc}$ AFC 
Electrical and Electronics Engineering: An International Journal (ELELIJ) Vol 4, No 4, November 2015

Findings of Figure 29, 30, 31 and 32 are summarized shown in Table VI.

Table 6.IMPORTANTS MEASUREMENTS OF FUEL SUPPLY PRESSURE

\begin{tabular}{|c|c|c|c|c|c|}
\hline \multirow{2}{*}{ System } & \multirow{2}{*}{$\begin{array}{c}\text { Time } \\
\text { (sec.) }\end{array}$} & \multicolumn{4}{|c|}{ Fuel Supply Pressure (Bar) } \\
\cline { 3 - 6 } & $\begin{array}{c}\text { Voltage } \\
\text { (Volts) }\end{array}$ & $\begin{array}{c}\text { Current } \\
\text { (Amp) }\end{array}$ & $\begin{array}{l}\text { DC bus } \\
\text { voltage } \\
\text { (Volts) }\end{array}$ & $\begin{array}{c}\text { DC bus } \\
\text { current } \\
\text { (Amp) }\end{array}$ \\
\hline \multirow{2}{*}{$\begin{array}{c}2.4 \mathrm{~kW}-48 \mathrm{Vdc} \\
\text { AFC }\end{array}$} & 0 & 63 & 0 & 125 & 0 \\
\cline { 2 - 6 } & 10 & 56 & 5 & 100 & 60 \\
\cline { 2 - 6 } & 20 & 59 & 12 & 100 & 60 \\
\hline
\end{tabular}

Findings of Figure $25 \& 33$ are summarized and shown in Table VII

Table 7.MEASUREMENTS OF SUPPLY PRESSURE

\begin{tabular}{|c|c|c|c|}
\hline \multirow[b]{2}{*}{ System } & \multirow[b]{2}{*}{$\begin{array}{l}\text { Time } \\
\text { (sec.) }\end{array}$} & \multicolumn{2}{|c|}{ Supply Pressure (Bar) } \\
\hline & & $\begin{array}{c}\text { Fuel Supply } \\
\text { Pressure }\end{array}$ & $\begin{array}{c}\text { Air Supply } \\
\text { Pressure }\end{array}$ \\
\hline \multirow{3}{*}{$2.4 \mathrm{~kW}-48 \mathrm{Vdc}$ AFC } & 0 & 0 & 0 \\
\hline & 10 & 85 & 5 \\
\hline & 20 & 85 & 85 \\
\hline
\end{tabular}

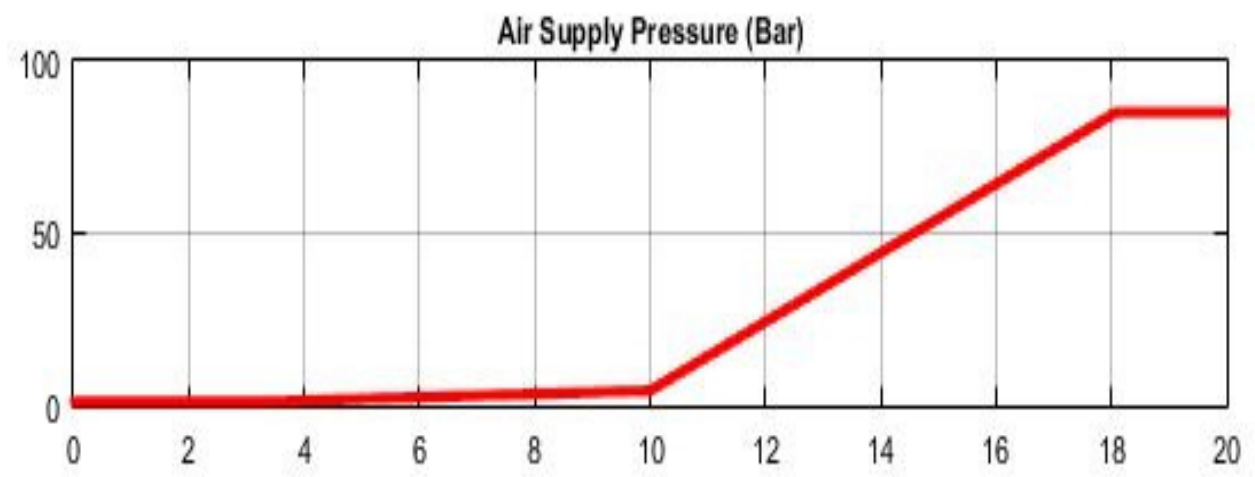

Fig.33. Air supply pressure (Bar) of $2.4 \mathrm{~kW}-48 \mathrm{Vdc}$ AFC 
Electrical and Electronics Engineering: An International Journal (ELELIJ) Vol 4, No 4, November 2015

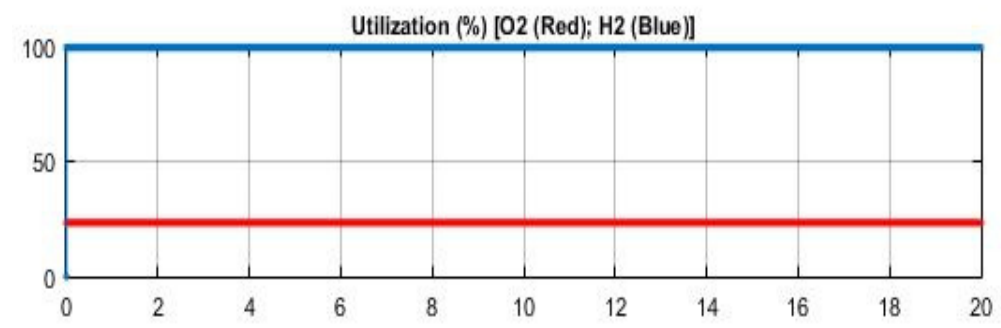

Fig.34. Utilization (\%) $\left[\mathrm{O}_{2}\right.$ (Red), $\mathrm{H}_{2}$ (Blue) $]$ of $2.4 \mathrm{~kW}-48 \mathrm{Vdc}$ AFC

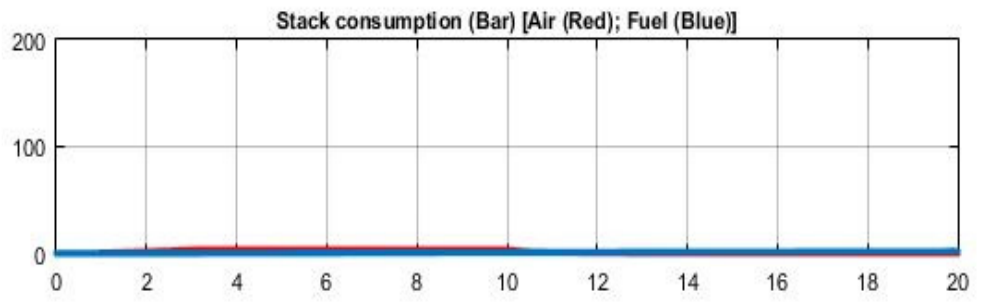

Fig.35. Stack consumption (Bar) [Air (Red), Fuel (Blue)] of 2.4 kW - 48 Vdc AFC

From Figure 34, can be concluded that the utilization of oxygen is about $25 \%$ whereas utilization of hydrogen is about $100 \%$. From Figure 35, can be concluded that the consumption of Air is about 0 Bar from $2 \mathrm{sec}$. to $10 \mathrm{sec}$. whereas Fuel consumption is almost 0 Bar from $0 \mathrm{sec}$. to 20 sec. From Figure 36, can be concluded that stack efficiency is $78 \%$ at 0 sec., at 10 sec. stack efficiency is $72 \%$ and at 20 sec. stack efficiency is about $76 \%$.

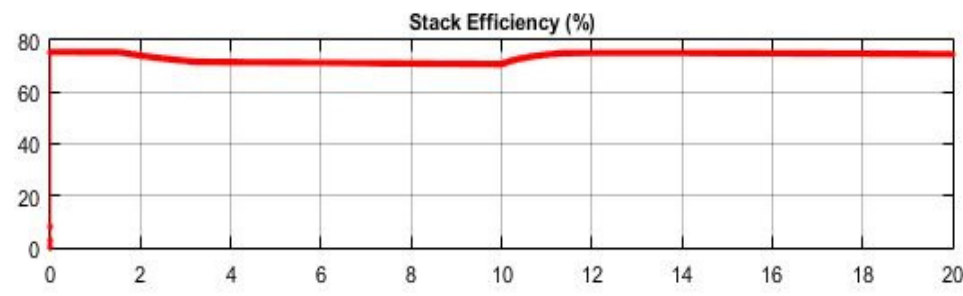

Fig.36. Stack efficiency (\%) of $2.4 \mathrm{~kW}-48 \mathrm{Vdc}$ AFC

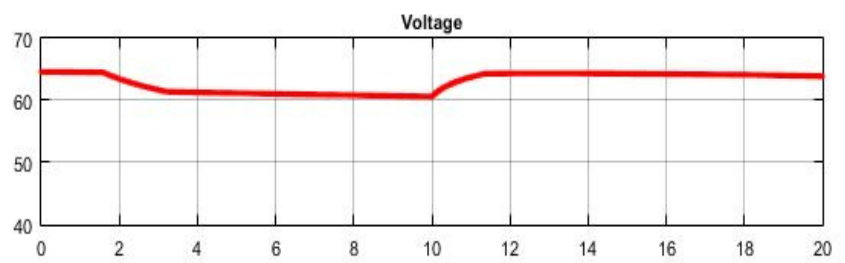

Fig.37. Fuel cell stack voltage of $2.4 \mathrm{~kW}-48 \mathrm{Vdc}$ AFC 
Electrical and Electronics Engineering: An International Journal (ELELIJ) Vol 4, No 4, November 2015

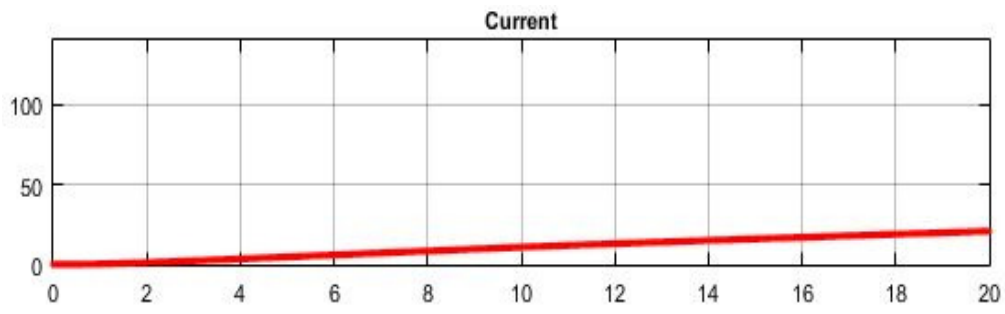

Fig.38. Fuel cell stack current of $2.4 \mathrm{~kW}-48$ Vdc AFC

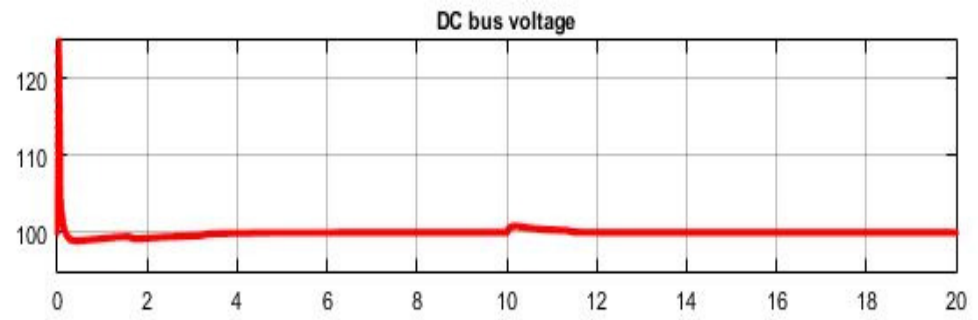

Fig.39. DC bus voltage of $2.4 \mathrm{~kW}-48 \mathrm{Vdc}$ AFC

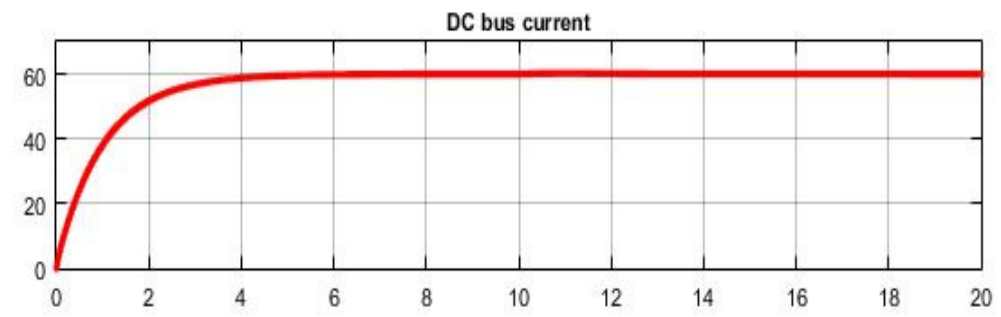

Fig.40. DC bus current of $2.4 \mathrm{~kW}-48 \mathrm{Vdc}$ AFC

Findings of Figure 37, 38, 39 and 40 are summarized and shown in Table VIII.

Table 8.IMPORTANT MEASUREMENTS OF AIR SUPPLy PRESSURE

\begin{tabular}{|c|c|c|c|c|c|}
\hline \multirow[b]{2}{*}{ System } & \multirow[b]{2}{*}{$\begin{array}{l}\text { Time } \\
\text { (sec.) }\end{array}$} & \multicolumn{4}{|c|}{ Air Supply Pressure (Bar) } \\
\hline & & $\begin{array}{l}\text { Voltage } \\
\text { (Volts) }\end{array}$ & $\begin{array}{c}\text { Current } \\
\text { (Amp) }\end{array}$ & $\begin{array}{l}\text { DC bus } \\
\text { voltage } \\
\text { (Volts) }\end{array}$ & $\begin{array}{l}\text { DC bus } \\
\text { current } \\
\text { (Amp) }\end{array}$ \\
\hline \multirow{3}{*}{$\begin{array}{c}2.4 \mathrm{~kW}-48 \mathrm{Vdc} \\
\mathrm{AFC}\end{array}$} & 0 & 65 & 0 & 125 & 0 \\
\hline & 10 & 60 & 4 & 100 & 60 \\
\hline & 20 & 64 & 11 & 100 & 60 \\
\hline
\end{tabular}




\section{Conclusions}

This paper has presented a study to investigate the output behavior of Alkaline Fuel Cell's parameters. Flow rate as well as supply pressure are important parameter of any type of fuel cell but these parameter are also important for Alkaline Fuel Cell (AFC) because AFC is used space, military, transportation and backup power. A detail model of simulink is employed in this analysis. The results obtained good output behavior as expected from manufacturer's data sheet. However, in future further study should be continued about $2.4 \mathrm{~kW}-48 \mathrm{Vdc}$ AFC taken into account of System temperature, Fuel composition and Oxidant composition of $2.4 \mathrm{~kW}-48 \mathrm{Vdc}$ AFC.

\section{ACKNOWLEDGEMENTS}

The authors would also like to show their gratitude to MathWorks for sharing their generic hydrogen fuel cell stack model $(6 \mathrm{~kW}-45 \mathrm{Vdc})$ of Proton Exchange Membrane Fuel Cell (PEMFC) during this research.

\section{REFERENCES}

[1] Fuel cells [online]. available: http://energy.gov/eere/fuelcells/fuel-cells.

[2] Types of fuel cells [online]. available: http://energy.gov/eere/fuelcells/types-fuel-cells.

[3] Fuel cell basics [online]. available: http://americanhistory.si.edu/fuelcells/basics.htm.

[4] Kirubakaran a, jain s, nema rk. a review on fuel cell technologies and power electronic interface. renew sustain energy rev2009;13:2430-40.

[5] Fuel mass flow rate [online]. available:https://www.grc.nasa.gov/www/k-12/airplane/fuelfl.html [6] code of federal regulations. the office of the federal register national archives and records administration, a special edition of the federal register, u.s. government printing office washington:2003.

[7] Fuel pressure explained [online]. available:http://injectordynamics.com/articles/fuel-pressureexplained/

[8] Fuel systems: gasoline fuel systems [online].

available:http://www.cdxetextbook.com/fuelsys/gasoline/topic.html

[9] Foyce, m.p. (2006), gas turbine engineering handbook, 3rd ed., gulf professional pub., boston.

[10] covert, e. e. (1985), thrust and drag: its prediction and verification, american institute of aeronautics and astronautics, new york.

[11] Types of fuel cell [online].available: http://energy.gov/eere/fuelcells/types-fuel-cells

[12] Lee, j. y., lee, h. h., lee, j. h., \& kim, d. m. (1997). u.s. patent no.5,599,640. washington, dc: u.s. patent and trademark office.

[13] Alhassan m, garba mu. design of an alkaline fuel cell. minna: federal university of technology;

2006.

[14] Redox reaction, wikipedia, the free encyclopaedia. available online at:

http://en.wikipedia.org/wiki/redox reaction [accessed 04.04.10].

[15] Andújar jm, segura f. fuel cells: history and updating. a walk along two centuries. renew sustain energy rev 2009;13:2309-22.

[16] Crawley g. fuel cell today. johnson matthey plc. 04241894; 2006,march. available online at: http://www.fuelcelltoday.com

[17] Fuel cell handbook. eg \& g technical services, inc. 7th ed. u.s.department of energy, office of fossil energy, national energy technology laboratory, morgantown west virginia: 2004. 
Electrical and Electronics Engineering: An International Journal (ELELIJ) Vol 4, No 4, November 2015

[18] Fuel cell stack [online].

available:http://www.mathworks.com/help/physmod/sps/powersys/ref/fuelcellstack.html

[19] Nedstack ps6 product data - fuel cell markets [online]. available:

www.fuelcellmarkets.com/content/images/articles/ps6.pdf 